УДК 332.14:339.97

Захарченко В.І., д.е.н., професор

Черкаський державний технологічний університет

\title{
СУПЕРПОЗИЦІЯ ОСНОВНИХ НАПРЯМІВ НОВОЇ РЕГІОНАЛЬНОЇ ПОЛІТИКИ УКРАЇНИ ТА РОЗВИНЕНИХ КРАЇН (У КОНТЕКСТІ ВИКОРИСТАННЯ ЗАРУБІЖНОГО ДОСВІДУ)
}

У статті розкрито особливості нової регіональної політики. Співставлено основні напрями цієї політики в Україні та в розвинених країнах. Проаналізовано (в аспекті запозичення зарубіжного досвіду) основні напрями нової регіональної політики розвинених країн: підвищення ролі децентралізації та регіоналізму; зменшення міжрегіональних диспропорцій; формування багатоцентрової територіальної структури; вирішення специфічних регіональних проблем; забезпечення конкурентоспроможності регіонів; забезпечення ендогенного, збалансованого та сталого розвитку регіонів; забезпечення сталості в розвитку регіонів. Підкреслено важливе значення належного інституційного забезпечення нової регіональної політики України на основі використанням досвіду розвинених країн.

Ключові слова: парадигма регіоналізму (старого, нового), регіональна політика, нова регіональна політика (України, розвинених країн), інституційне забезпечення нової регіональної політики.

Zakharchenko V.

\section{THE SUPERPOSITION OF THE MAIN DIRECTIONS OF THE NEW REGIONAL POLICIES OF UKRAINE AND DEVELOPED COUNTRIES (IN CONTEXT USE OF FOREIGN EXPERIENCE)}

The article reveals the features of the new regional policy. The main directions of this policy are compared in Ukraine and in developed countries. The main directions of the new regional policy of the developed countries are analyzed (in terms of borrowing from foreign experience): enhancing the role of decentralization and regionalism; reducing inter-regional disparities; formation of a multicenter territorial structure; solving specific regional problems; ensuring the competitiveness of regions; ensuring endogenous, balanced and sustainable development of regions; ensuring sustainability in regional development. The importance of proper institutional support for Ukraine's new regional policy, based on the experience of developed countries, is emphasized.

Key words: paradigm of regionalism (old, new), regional policy, new regional policy (Ukraine, developed countries), institutional support of new regional policy.

Захарченко В.И.

\section{СУПЕРПОЗИЦИЯ ОСНОВНЫХ НАПРАВЛЕНИЙ НОВОЙ РЕГИОНАЛЬНОЙ ПОЛИТИКИ УКРАИНЫ И РАЗВИТЫХ СТРАН (В КОНТЕКСТЕ ИСПОЛЬЗОВАНИЯ ЗАРУБЕЖНОГО ОПЫТА)}

В статье раскрыты особенности новой региональной политики. Сопоставлены основные направления этой политики в Украине и в развитых странах. Проанализированы (в аспекте заимствования зарубежного опыта) Основные направления новой региональной политики развитых стран: повышение роли децентрализации и регионализма; уменьшение межрегиональных диспропорций; формирование многоцентровых территориальной структуры; решения специфических региональных проблем; обеспечение конкурентоспособности регионов; обеспечение эндогенного, сбалансированного и устойчивого развития регионов; обеспечение устойчивости в развитии регионов. Подчеркнуто важное значение надлежащего институционального обеспечения новой региональной политики Украины на основе использованием опыта развитых стран.

Ключевые слова: парадигма регионализма (старого, нового), региональная политика, новая региональная политика (Украина, развитых стран), институциональное обеспечение новой региональной политики. 
Постановка проблеми у загальному вигляді i ï зв'язок 3 важливими науковими та практичними завданнями. 3 кінця 1980-х pp. у економічно розвинених країнах, зокрема тих, що входять до Організації економічного співробітництва та розвитку (ОЕСР), Китаї та інших, реалізується нова регіональна політика. Її особливістю $\epsilon$ те, що вона поступово відходить від парадигми старого регіоналізму, в якій робився акцент на підтримці відсталих регіонів і територій за рахунок прямих фінансових вливань держави, і переходить на засади парадигми нового регіоналізму, в якій на перший план виходить державне стимулювання саморозвитку регіонів і територій.

Для України, яка 3 перших років незалежності взяла курс на формування i проведення нової регіональної політики, і закріпила цей курс у Законі «Про засади державної регіональної політики» (від 5 лютого 2015 р. № 156-VIII), особливо важливе значення має врахування досвіду розвинених країн у розрізі основних напрямів цієї політики, які зазвичай вибудовуються навколо деяких найважливіших цілей та шляхів їх досягнення.

Аналіз останніх досліджень, у яких започатковано вирішення проблеми. Значний внесок в обгрунтування можливостей запровадження зарубіжного досвіду проведення нової регіональної політики в українську практику зробили такі вітчизняні й зарубіжні вчені, як Р. Гуле [1], М. Долішній [2], А. Кінщак [3], С. Лучик та В. Лучик [4], В. Решетило та Г. Стадник [5], І. Сторонянська та А. Прокоп'юк [6], В. Чужиков [7] та ін. Однак у їхніх працях немає чітко вираженого співставлення основних напрямів нової регіональної політики Україні та розвинених країн, що не сприяє цілеспрямованому запровадженню зарубіжного досвіду.

Цілі статті. Мета дослідження полягає в суперпозиції (накладанні та порівнянні) основних напрямів нової регіональної політики України та розвинених країн у контексті цілеспрямованого використання позитивного зарубіжного досвіду.

Виклад основного матеріалу дослідження 3 повним обгрунтуванням отриманих наукових результатів. В одній 3 попередніх публікацій нами запропоновано виокремлювати такі основні напрями нової регіональної політики України: 1) міжрегіональна інтеграція в межах національної держави; 2) подолання асиметрії в рівнях розвитку регіонів; 3) планування і регулювання розвитку територій; 4) адаптація регіонів до умов глобалізації та регіоналізації; 5) підвищення конкурентоспроможності регіонів (див. [8]). Їх суперпозиція з аналогічними напрямами нової регіональної політики розвинених країн показує, що вони кореспондують між собою (табл. 1).

Таблиця 1

Суперпозиція основних напрямів нової регіональної політики в Україні та в розвинених країнах

\begin{tabular}{|c|c|c|}
\hline \multirow{2}{*}{$\begin{array}{c}\text { Основні напрями } \\
\text { нової регіональної } \\
\text { політики в Україні }\end{array}$} & \multicolumn{2}{|c|}{ Нова регіональна політика в розвинених країнах } \\
\hline & основні напрями & вияви та результати проведення \\
\hline \multirow{2}{*}{$\begin{array}{l}\text { Міжрегіональна } \\
\text { інтеграція в межах } \\
\text { національної держави }\end{array}$} & $\begin{array}{lr}\text { Підвищення } & \text { ролі } \\
\text { децентралізації } & \text { та }\end{array}$ & $\begin{array}{l}\text { Підвищення ролі регіональної та місцевої влади на фоні } \\
\text { скорочення обов’язків державної адміністрації }\end{array}$ \\
\hline & регіоналізму & $\begin{array}{l}\text { Забезпечення не тільки соціальної і економічної, а й } \\
\text { екологічної, політичної та культурної безпеки }\end{array}$ \\
\hline $\begin{array}{l}\text { Подолання асиметрії в } \\
\text { рівнях } \\
\text { регіонів }\end{array}$ & $\begin{array}{l}\text { Зменшення } \\
\text { міжрегіональних } \\
\text { диспропорцій }\end{array}$ & $\begin{array}{l}\text { Тенденції до функціональної та організаційної } \\
\text { інтеграції макропросторової та регіональної політики }\end{array}$ \\
\hline
\end{tabular}


продовження таблиці 1.

\begin{tabular}{|c|c|c|}
\hline 1 & 2 & 3 \\
\hline $\begin{array}{ll}\text { Планування } \\
\text { регулювання } \\
\text { розвитку територій }\end{array}$ & $\begin{array}{l}\text { Формування } \\
\text { багатоцентрової } \\
\text { територіальної } \\
\text { структури }\end{array}$ & $\begin{array}{l}\text { Акцент на забезпечення мобільності суспільства і } \\
\text { підвищення територіальної доступності окремих міст і } \\
\text { регіонів за рахунок розвитку транспортних зв’язків, що } \\
\text { призводить до більш високого ступеня територіальної } \\
\text { згуртованості }\end{array}$ \\
\hline $\begin{array}{l}\text { Адаптація регіонів до } \\
\text { умов глобалізації та } \\
\text { регіоналізації }\end{array}$ & $\begin{array}{l}\text { Вирішення } \\
\text { специфічних } \\
\text { регіональних } \\
\text { проблем }\end{array}$ & $\begin{array}{l}\text { Урахування при розробці та реалізації сучасної } \\
\text { регіональної політики нових соціально-економічних } \\
\text { проблем, які пов'язані із глобалізацією економіки, } \\
\text { змінами клімату, несприятливими демографічними } \\
\text { процесами, зростанням цін на енергоресурси }\end{array}$ \\
\hline \multirow[t]{5}{*}{$\begin{array}{l}\text { Підвищення } \\
\text { конкурентоспроможн } \\
\text { ості регіонів }\end{array}$} & \multirow[t]{2}{*}{$\begin{array}{l}\text { Забезпечення } \\
\text { конкурентоспромож } \\
\text { ності регіонів }\end{array}$} & $\begin{array}{l}\text { Створення мережевих структур за рахунок } \\
\text { забезпечення співробітництва державних органів різних } \\
\text { рівнів та їх економічних і соціальних партнерів як } \\
\text { важливого стимулу зростання }\end{array}$ \\
\hline & & 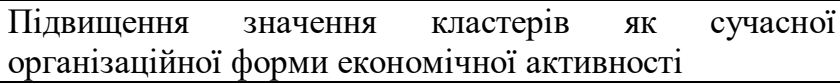 \\
\hline & \multirow{2}{*}{$\begin{array}{l}\text { Забезпечення } \\
\text { ендогенного, } \\
\text { збалансованого та } \\
\text { сталого розвитку } \\
\text { регіонів }\end{array}$} & $\begin{array}{l}\text { Зосередження уваги на розвитку ендогенного } \\
\text { потенціалу регіону, а не на екзогенних заходах та } \\
\text { інвестиціях }\end{array}$ \\
\hline & & $\begin{array}{l}\text { Підвищення значення малих та середніх підприємств } \\
\text { для соціально-економічного розвитку регіонів }\end{array}$ \\
\hline & $\begin{array}{l}\text { Забезпечення } \\
\text { сталості в розвитку } \\
\text { регіонів }\end{array}$ & $\begin{array}{l}\text { Зміщення державних пріоритетів } 3 \text { матеріального } \\
\text { виробництва до сфери послуг }\end{array}$ \\
\hline
\end{tabular}

Джерело: складено автором на основі власних розробок та джерел [9, с. 16; 10].

Співпадання (повне чи часткове) напрямів нової регіональної політики України та розвинених країн розширює можливості щодо використання зарубіжного досвіду у вітчизняній практиці. Розглянемо їх за основними напрямами нової регіональної політики розвинених країн.

Підвищення ролі дещентралізащії та регіоналізму. В багатьох розвинених країнах вважається, що уникнути небажаних наслідків відцентрових тенденцій, засадах можна на засадах досягнення регіонами політичної та фінансово-економічної самостійності на засадах регіоналізму - західного (європейського), американського чи східного.

Особливо цінний досвід у плані вирішення конфліктів між центром та регіонами, що взяли курс на сепаратизм (широку автономію чи проголошення незалежності), нагромаджено в Свропі, зокрема у Великій Британії та Іспанії. У першій із цих країн проводиться політика, спрямована на широку дискусію щодо переваг і недоліків виходу 3 країни окремих іiі частин (Шотландії та Уельсу), розширення представництва націоналістичних партій у їх парламентах та парламенті країни й організацію демократичного волевиявлення громадян «бунтівних регіонів», свідченням чого став референдум про незалежність Шотландії у вересні 2014 р. В Іспанії упокорення «бунтівних регіонів» проводиться на засадах дотримання іiі конституції, яка не передбачає виходу Каталогії та Країни Басків з ії складу, але передбачає надання їм широких прав автономії. Більш правильною нам видається британська політика, яка узгоджена $з$ Декларацією ООН про права корінних народів і підтверджує право цих народів на самовизначення. Відповідно, українська держава в рамках своєї регіональної політики має надати таке право кримським татарам, караїмам і кримчакам, але аж ніяк не населенню Криму (крім корінних народів) і Донбасу.

В плані фінансово-економічної самостійності регіонів прикладом можуть слугувати США, де у взаємовідносинах між центром і регіонами досить успішно практикується модель конкурентного федералізму, яка передбачає високий ступінь фіскальної і бюджетної автономії регіонів (штатів). При цьому значна автономність 
регіональних бюджетів не складає загроз для формування національного, зокрема оборонного, бюджету. В Україні цей критерій також має визначати рівень економічного, зокрема бюджетного, регіоналізму.

Зменшення міжрегіональних диспропорцій. У більшості розвинених країн цього досягають шляхом підтримки (в контексті старого регіоналізму) та стимулювання (в контексті нового регіоналізму) розвитку відсталих регіонів. При цьому враховується групування регіонів за рівнем і проблемністю їхнього розвитку. Для України досить цікавим у цьому плані є досвід Німеччини, яка постійно переглядає вимоги до визнання регіонів проблемними. У 2007 р. в країні кількість категорій проблемних регіонів скорочено до двох: економічно відсталих (А) і регіонів зі структурними проблемами (C). Виділені також додаткові зони (Д), для яких дозволена лише підтримка інвестицій малого і середнього бізнесу, стимулювання розвитку інфраструктури та сприяння реалізації кластерних проектів [4, с. 126].

Звичайно, інституційне забезпечення та набір інструментів із подолання міжрегіональних диспропорцій може бути різним. Так, у США важливу роль у підтриманні відсталих регіонів відігравали агентства регіонального розвитку, зокрема такі як державна інвестиційна корпорація «Адміністрація долини Теннессі», яка була створена ще у 1930-х рр. В основу їхньої діяльності покладена політика концентрації державних інвестицій на економічно відсталих територіях та реалізація регіональних програм. Згодом від політики прямої підтримки регіонів в країні перейшли до політики стимулювання їхнього розвитку. В умовах децентралізації влади це часто набувало форм дольового фінансування регіональних проектів - за рахунок коштів федерального центру, штатів, округів і місцевих громад. Звичайно, це сприяло об'єднанню інтересів щодо підйому відсталих територій, зокрема 13 штатів уздовж Аппалачських гір, усіх зацікавлених сторін та спричинювало виникнення синергетичного ефекту (ефекту співучасті). Для протидії проявам криз, зокрема світової фінансової 2008 р., в 47 штатах та в окрузі Колумбія прийняті спеціальні програми антикризових дій.

У інших розвинених країнах для розвитку відсталих або депресивних районів також застосовуються не стільки інструменти їх підтримки (пряма фінансова допомога, реалізація державних цільових програм), скільки інструменти стимулювання розвитку: угоди між урядом і бізнесом (Франція), державно-приватне партнерство на основі моделі «спільної участі у вирішенні завдань» (Німеччина), створення регіональних та муніципальних корпорацій (Японія), часткове або повне звільнення від податків та застосування прискореної амортизації, технологічна реструктуризація економіки, розвиток місцевого бізнесу [3, с. 194-195].

В Україні доцільним $є$ використання практично усіх із наведених інструментів подолання асиметрії в рівнях розвитку регіонів, навіть такого, як формування муніципальних корпорацій, оскільки він сприяє зміцненню фінансово-економічної бази територіальних громад, а отже, досягненню стратегічних цілей реформи децентралізації,

Формування багатоиентрової територіальної структури. У багатьох країнах спостерігається надмірна концентрація населення та економічної діяльності у великих містах і агломераціях, що об'єктивно потребує їх «розвантаження». Так, у Франції підтримуються заходи 3 територіальної декоцентрації промислової діяльності із столичного регіону Іль-де-Франс (Великий Париж) у метрополії другого порядку (Марсель, Ліон, Нант). Причому держава компенсує до 60 \% витрат на переміщення промислових потужностей [11, с. 115]. В Україні цей досвід особливо важливий у зв'язку з проблемою «розвантаження» Київської міської агломерації, яка має тенденції до загострення в плані наявності вільних земель, інфраструктурного забезпечення, якості довкілля тощо.

Передбачається, що цей процес має супроводжуватися формування нових полюсів зростання різного рангу та поширення їх позитивного впливу на периферію, спрямованого на розвиток відсталих (сільських та центральних гірських) регіонів 
територій. В Італії ключовою регіональною проблемою вважається подолання розривів у рівнях розвитку Півночі і Півдня. Але спроби їі вирішення на основі розробленого ще у 1956 р. «Плану Ваноні» зі створення на Півдні країни додаткових промислових потужностей та формування там у 1970-х рр. нових полюсів зростання відіграли позитивну роль, але повністю не закрили проблему, бо їх об'єкти слабо «вписалися» в структуру економіки Півдня. В Україні важливо, щоб полюсами розвитку виступали не тільки столиця, обласні центри, великі міста, міста-супутники (Бровари, Бориспіль та ін.), а й більшість малих та середніх міст, бо це чи не основна умова економічного підйому відсталих регіонів і територій.

Вирішення спещиффічних регіональних проблем. Основні 3 них пов'язані 3 глобалізацією, змінами клімату, несприятливими демографічними процесами та зростанням цін на енергоресурси. Зрозуміло, вони потребують врахування при проведенні регіональної політики. Так, реакцією на активізацію процесів глобалізації в зарубіжних країнах $є$ участь національних регіонів i ïx частин у формуванні транснаціональних мережевих структур (ТНК та ін.). Внаслідок цього вони стають «Глобальними гравцями», підсистемами світової економіки, а ТНК в їх економіці відіграють провідну роль, як наприклад в регіоні Камсай, що в Японії, до якого входять міста Осака, Кобе та Кіото. В Україні транснаціоналізація економіки регіонів також $є$ одним із найперспективніших напрямів іiі розвитку, вирішення багатьох не тільки регіональних, а й загальнодержавних проблем. Але це можливо за умови, що в країну прийдуть компанії - світові інноваційні лідери, а не аутсайдери типу корейської Деу (Daewoo), яка «завалила» АвтоЗАЗ та ряд підприємств-суміжників, у т. ч. у Запорізькій області (у Мелітополі, Пологах та ін.).

Для активізації міжнародного співробітництва та вирішення конкретних регіональних проблем створені такі міжнародні об'єднання регіонів, як Асоціація європейських регіонів (вона включає такі «Чотири двигуни Свропи», як німецька земля Баден-Вюртемберг, іспанська Каталонія, італійська Ломбардія та французький регіон Рон-Альпи), Конференція периферійних приморських регіонів, Робоча група традиційних індустріальних регіонів.

Для українських регіонів і територіальних громад більш важливим є укладання угод в рамках єврорегіонів, утворених спільно з країнами СС («Карпати-Україна», «Буг», «Нижній Дунай», «Верхній Прут») та 3 країнами, які не $є$ членами ЄС («Дністер», «Дніпро», «Слобожанщина», «Ярославна», «Донбас»). На жаль, збройна агресія РФ проти України з 2014 р. призвела до припинення співпраці в рамках трьох останніх єврорегіонів.

Забезпечення конкурентоспроможності регіонів. Ніщо так не підштовхує країни і їхні регіони до підвищення конкурентоспроможності як глобалізація. Відповідно на перший план виходить завдання щодо підвищення міжнародної конкурентоспроможності національних регіонів. Шляхів для цього є дуже багато. I вже згаданий шлях транснаціоналізації економіки регіону, і іï мережної організації та кластеризації, і технологічної реструктуризації і багато інших. Нині високого рівня міжнародної конкурентоспроможності у США досяг регіон (штат) Нью-Йорк, у Китаї спеціальний адміністративний район Гонконг, у Японії - регіон Камсай, у Німеччині земля Баварія, у Франції - регіон Іль-де-Франс, у Італії - провінція Ломбардія, у Іспанії - провінція Каталонія. В Україні серед регіонів найвищий рівень міжнародної конкурентоспроможності має м. Київ, але для більшості регіонів він $є$ досить низьким. Тому для України особливо цінним може бути досвід: Німеччини - 3 підвищення конкурентоспроможності східних земель - через реалізацію федеральних проектів 3 корпоратизації та модернізації місцевих промислових підприємств; Китаю - зі створення вільних економічних зон і технопарків у тих регіонах, які мають для цього найкращі можливості, хоча це може й поглиблювати асиметрію в регіональному розвитку країни; 
Японії - з реалізації програм переспеціалізації промисловості та розвитку виробничої інфраструктури окремих регіонів.

Забезпечення ендогенного, збалансованого та сталого розвитку регіонів. Для досягнення високих показників регіональної конкурентоспроможності в зарубіжних країнах значну увагу приділяють використанню ендогенних місцевих активів і знань на основі співпраці 3 регіональною $\mathrm{i}$ місцевою владою, що $\epsilon$ запорукою сталого (збалансованого) розвитку регіонів і їх частин. В цьому зв'язку важливе значення має смарт-спеціалізація регіонів та виникнення смарт-міст, що пов'язується із самим широким використанням місцевих активів на основі інновацій. Нині значні успіхи у смарт-спеціалізації регіонів досягнуто у країнах $€ C$, але він набуває популярності і в інших країнах світу, в т. ч. й Україні (в Одеській, Дніпропетровській, Закарпатській та Черкаській областях). Особливу цінність представляє досвід реструктуризації (на засадах смарт-спеціалізації) старопромислових регіонів у Великій Британії, Польщі та, особливо, у Німеччині. Його в Україні слід враховувати при визначенні напрямів смартспеціалізації та реструктуризації (на основі «Індустрії 4.0») старопромислових шахтарських регіонів.

Забезпечення сталості в розвитку регіонів. Це досягається насамперед на основі зміщення державних пріоритетів в розвитку регіональної економіки з матеріального виробництва до сфери послуг. Так, творення туристичних центрів, наприклад у Туреччині, сприяло сталому розвитку багатьох регіонів, зокрема Анталії. В Україні також є багато можливостей для забезпечення сталого розвитку Києва, Карпатського, Причорноморського й інших регіонів за рахунок сервісних видів діяльності.

Для проведення нової регіональної політики в розвинених країнах важливе значення має ii інституційне забезпечення. В окремих країнах ii формуванням i проведенням опікуються самі різні інституції: профільні міністерства чи спеціальні державні органи, наприклад, DATAR у Франції, Міністерство регіонального розвитку у Чехії; уповноважені державні органи, наприклад Управління економічного планування у Японії, Федеральне управління будівництва та організації території у Німеччині; спеціальні агенції, фонди тощо, наприклад, державні інвестиційні корпорації у США, Національна асоціація агентств регіонального розвитку у Польщі, Фонд регіонального розвитку та збереження заселення сільських районів у Словенії. Для України найбільш прийнятним є досвід країн, у яких для розробки та проведення нової регіональної політики утворено спеціальний державний орган. Таким органом в реаліях України має стати Міністерство розвитку громад та територій.

Звичайно, проведення ефективної регіональної політики $\epsilon$ неможливим без формування необхідних інститутів, передусім відповідного законодавства. На нашу думку, найбільш усталені законодавчі норми регіональної політики сформовані у США та в європейських країнах. Так, у США законом «Про громадські роботи та економічний розвиток» від 1965 р. чітко визначено типи проблемних територій та способи державної підтримки їхнього розвитку. У Франції важливу інституційну роль у сфері нової регіональної політики, окрім спеціальних законів, відіграють угоди між державою та регіонами терміном на 7 років. Практика таких угод має місце і в Україні.

Законодавча база нової регіональної політики європейських країн також включає міжнародні документи: Хартію з регіоналізму (1988р.), Свропейську хартію місцевого самоврядування (1994 р.), Декларацію про регіоналізм (1996 р.) та ін.

Висновки. В Україні з перших років незалежності цілком виправдано взято курс на проведення нової регіональної політики з акцентом не на пряму фінансову підтримку держави регіонів, а на стимулювання їхнього саморозвитку. Основні напрями цієї політики тісно кореспондують з основними напрямами аналогічної політики розвинених країн, тому їх суперпозиція дозволяє віднайти додаткові можливості для використання зарубіжного досвіду в умовах України. Важливе значення має й використання в Україні деяких складових інституційного базису нової регіональної політики розвинених країн. 


\section{Список бібліографічного опису:}

1. Свропейська регіональна політика: натхнення для країн, що не входять до СС? / за ред. Рафаеля Гуле; Головне управління регіональної політики Європ. комісії. Брюссель: Офіс офіц. публікацій ЄC, 2009. 16 с. URL: https://ec.europa.eu/regional_policy/sources/docgener/presenta/international/external_uk.pdf (дата звернення: 08.01.2020).

2. Долішній М. І. Регіональна політика на рубежі XX - XXI століть: нові пріоритети. Київ: Наук. думка, 2006. 512 с.

3. Кінщак А. В. Світовий досвід формування політики регіонального розвитку. Вісник Національного університету цивільного захисту України. Серія: Державне управління. 2015. Вип. 2. С. 187-196.

4. Лучик С. Д., Лучик В. Є. Світовий досвід формування та реалізації політики регіонального розвитку та можливість його запровадження в Україні. Науковий вісник НЛТУ України. 2013. Вип. 23.18. С. 124-131.

5. Решетило В. П., Стадник Г. В. Мировой опыт проведения политики регионального развития и возможности его использования в Украине. Комунальне господарство міст: наук.-техн. зб. Серія: Економічні науки. 2012. Вип. 102. C. 3-10.

6. Storonyanska I. Z., Prokopiuk A. The new model of regional development: Polish experience and vectors for Ukraine. Регіональна економіка. 2018. № 2. С. 89-97.

7. Чужиков В. І. Глобальна регіоналістика: історія та сучасна методологія: монографія. Київ: КНЕУ, 2008.272 с.

8. Захарченко В. І. Теоретичне обгрунтування нової регіональної політики. Економічний форум. 2019. № 4. С. $72-82$.

9. Regional Development Policies in OECD Countries, 2010. URL: http://www.planejamento.gov.br/secretarias/upload /Arquivos/seges/arquivos/ OCDE2011/OECD_Regional_Countries.pdf (дата звернення: 11.01.2020).

10. Szlachta J., Zaucha J. A New Paradigm of EU Regional Development in the Context of the Poland's National Spatial Development Concept. Sopot: Instytut Rozwoju, 2010. 17 p. URL: http://www.instytut-rozwoju.org/WP/IR_WP_1.pdf (дата звернення: 11.01.2020).

11. Сидоренко О. В., Бондаренко Т. Н. Селективная региональная политика государства. Вестник Томского государственного университета. Экономика. 2014. № 3. С. 110-117.

\section{References:}

1. Свропейська регіональна політика: натхнення для країн, що не входять до ЄС? / за ред. Рафаеля Гуле; Головне управління регіональної політики Європ. комісії. Брюссель: Офіс офіц. публікацій EC, 2009. 16 с. URL: https://ec.europa.eu/regional_policy/sources/docgener/presenta/international/external_uk.pdf (дата звернення: 08.01.2020). Goule, R. etc. (2009). Ievropeiska rehionalna polityka: natkhnennia dlia krain, shcho ne vkhodiat do YeS? [European regional policy: inspiration for non-EU countries?] / Holovne upravlinnia rehionalnoi polityky Yevrop. Komisii - European Regional Policy Directorate General. commissions. Briussel: Ofis ofits. publikatsii YeS. Retrieved from https://ec.europa.eu/regional_policy/sources/docgener/presenta/international/external_uk.pdf [in Ukrainian].

2. Dolishnii, M. I. (2006). Rehionalna polityka na rubezhi XX - XXI stolit: novi priorytety [Regional policy at the turn of the XX - XXI centuries: new priorities]. Kyiv: Naukova dumka [in Ukrainian].

3. Kinshchak, A. V. (2015). Svitovyi dosvid formuvannia polityky rehionalnoho rozvytku [World experience in regional policy development]. Visnyk Natsionalnoho universytetu tsyvilnoho zakhystu Ukrainy. Seriia: Derzhavne upravlinnia Bulletin of the National University of Civil Protection of Ukraine. Series: Public Administration, 2, 187-196 [in Ukrainian]. 4. Luchyk, S. D. \& Luchyk, V. Ye. (2013). Svitovyi dosvid formuvannia ta realizatsii polityky rehionalnoho rozvytku ta mozhlyvist yoho zaprovadzhennia $v$ Ukraini [World experience in the formulation and implementation of regional development policy and the possibility of its implementation in Ukraine]. Naukovyi visnyk NLTU Ukrainy - Scientific Bulletin of NLTU of Ukraine, 23.18, 124-131 [in Ukrainian].

5. Reshetilo, V. P. \& Stadnik, G. V. (2012). Mirovoy opyit provedeniya politiki regionalnogo razvitiya i vozmozhnosti ego ispolzovaniya $v$ Ukraine [World experience in the implementation of regional development policy and the possibility of its use in Ukraine]. Komunalne hospodarstvo mist: nauk.-tekhn. zb. Seriia: Ekonomichni nauky - Utilities of the cities: scientific-technical. Sat. Series: Economic Sciences, 102, 3-10 [in Russian].

6. Storonyanska I. Z., Prokopiuk A. The new model of regional development: Polish experience and vectors for Ukraine. Регіональна економіка. 2018. № 2. С. 89-97.

Storonyanska, I. Z. \& Prokopiuk, A. (2018). The new model of regional development: Polish experience and vectors for Ukraine. Rehionalna ekonomika - Regional economy, 2, 89-97.

7. Chuzhykov, V. I. (2008). Hlobalna rehionalistyka: istoriia ta suchasna metodolohiia: monohrafiia [Global regionalism: history and modern methodology: monograph]. Kyiv: KNEU [in Ukrainian].

8. Zakharchenko, V. I. (2019). Teoretychne obhruntuvannia novoi rehionalnoi polityky [Theoretical substantiation of the new regional policy]. Ekonomichnyi forum - Economic Forum, № 4, 72-82 [in Ukrainian].

9. Regional Development Policies in OECD Countries, 2010. URL: http://www.planejamento.gov.br/secretarias/upload /Arquivos/seges/arquivos/ OCDE2011/OECD_Regional_Countries.pdf (дата звернення: 11.01.2020).

Regional Development Policies in OECD Countries (2010). Retrieved from http://www.planejamento.gov.br/secretarias/upload/Arquivos/seges/arquivos/ OCDE2011/OECD_Regional_Countries.pdf 10. Szlachta J., Zaucha J. A New Paradigm of EU Regional Development in the Context of the Poland's National Spatial Development Concept. Sopot: Instytut Rozwoju, 2010. 17 p. URL: http://www.instytut-rozwoju.org/WP/IR_WP_1.pdf (дата звернення: 11.01.2020).

Szlachta, J. \& Zaucha, J. (2010). A New Paradigm of EU Regional Development in the Context of the Polands National Spatial Development Concept. Sopot: Instytut Rozwoju. Retrieved from http://www.instytut-rozwoju.org/WP/IR_WP_1.pdf

11. Sidorenko, O. V. \& Bondarenko, T. N. (2014). Selektivnaya regionalnaya politika gosudarstva [Selective regional state policy]. Vestnik Tomskogo gosudarstvennogo universiteta. Ekonomika - Bulletin of the Tomsk State University. Economics, 3, 110-117 [in Russian]. 